\title{
EFFECTS OF ORGANIC MANURE ON THE QUALITY OF COCONUT SOILS
}

\author{
N.A. TENNAKOON $\downarrow$, R. MAHINDAPALA ${ }^{1}$ and S. WIDANAPATHIRANA ${ }^{2}$ \\ ${ }^{1}$ Cocount Research Institute, Lunuwila. \\ ${ }^{2}$ Department of Microbiology, University of Kelaniya, Kelaniya.
}

(Received: 20 February 1995; accepted:06 October 1995)

\begin{abstract}
The performance of goat dung in gravel soil commonly found in coconut lands of the low country wet zone was investigated. Goat dung was applied at the rates of 18 and $24 \mathrm{~kg} / \mathrm{palm} /$ year and compared with treatments comprising recommended inorganic coconut fertilizer mixture $\left(\mathrm{CU}_{1}\right)$ and the control (only dolomite). Dolomite at the rate of $500 \mathrm{~g} / \mathrm{palm} /$ year was included in all treatments as a basal application.

The microbiological (i.e. total bacterial count, total fungal count, biomass $C$, $\mathrm{CO}_{2}$ evolution, $\mathrm{N}$ mineralization rate, nitrification), chemical (i.e. total $\mathbf{N}$, available $P$, exchangeable $K$ ) and physical (i.e. moisture) changes of soil after the application of various treatments were assessed over a 12 month period. Application of organic manure supplemented with inorganic fertilizers and only inorganic fertilizer mixture, significantly increased ( $p \leq 0.001)$ microbial counts and microbiologically mediated processes in the soil compared with the control. Addition of goat dung supplemented with inorganics brought about significantly higher ( $p \leq 0.001$ ) microbiological activity in the soil over only inorganic fertilizer treatment. The microbiological parameters showed positive correlation with physical/chemical parameters. Important yield parameters of coconut such as female flowers, number of nuts and copra content per palm per year also showed increases of $49 \%, 61 \% \& 58 \%$, respectively in treated palms compared with control in the third year after the application of manure/fertilizer. Organic manure treated palms gave a significant increase ( $p \leq 0.05$, only in the female flower production.
\end{abstract}

Keywords: Coconut soil, goat dung, organic manure.

\section{INTRODUCTION}

Animal manures, crop residues, green manures and compost are frequently used in developing countries to maintain or to improve fertility of soil, soil physical parameters and productivity. Many studies demonstrate that the application of organic manure enhances the microbial processes in the soils. ${ }^{1,2}$. High organic matter content in soils is generally associated with greater water holding capacity. ${ }^{3.5}$ The objective of this study was to investigate the microbiological and certain physical and chemical parameters over a 12 month period after application of inorganic and organic manure to coconut soil and assess the effect of inorganic and organic manure on the yield of coconut.

\section{METHODS AND MATERIALS}

Location: This experiment was carried out in a coconut estate, Divulapitiya situated in the low country wet zone. The annual rainfall of this region was 2200$2500 \mathrm{~mm}$ during the experimental period. The soil was a yellowish brown, sandy 
clay loam with ironstone in the surface; and below $36 \mathrm{~cm}$, the horizon passes to a sandy clay with lateritic gravel.

Experimental design: The design of the experiment was randomized block design with three replicates. A block consisted of 4 plots each having eight effective palms bound by a guard row.

Fertilizer combinations and applications: Four different combinations of ferti. lizer treatments were applied into 4 plots in a block as follows:

$\mathrm{T} 1$ - control (only dolomite $500 \mathrm{~g}$ ),

T2 - Inorganic fertilizer (NPK + dolomite) - recommended inorganic fertilizer mixture for coconut (urea $700 \mathrm{~g}$, saphos phosphate $700 \mathrm{~g}$, muriate of potash $1600 \mathrm{~g}$ and dolomite $500 \mathrm{~g}$ )

T3 - Organic manure (GD) + Inorganic fertilizer (NPK + dolomite) - goat dung 18kg, urea $50 \mathrm{~g}$, saphos phosphate $150 \mathrm{~g}$, muriate of potash $1200 \mathrm{~g}$, dolomite $500 \mathrm{~g}$ T4 - Organic manure (GD) + Inorganic fertilizer ( $\mathrm{K}+$ dolomite) - goat dung $24 \mathrm{~kg}$, muriate of potash $1070 \mathrm{~g}$, dolomite $500 \mathrm{~g}$. The concentrations of $\mathrm{N}, \mathrm{P}_{2} \mathrm{O}_{5}, \mathrm{~K}_{2} \mathrm{O}$ and $\mathrm{MgO}$ of dried goat dung were $2.1 \%, 0.7 \%, 1.5 \%$ and $1.3 \%$ respectively.

These fertilizer combinations were applied per palm per year. The nutrient composition was based on the recommended inorganic coconut fertilizer mixture. ${ }^{6}$ Fertilizer combinations were applied in the entire area round the base of the palms upto a distance of 1.75 meters from the base of the coconut palm.

Soil: Sampling: Soil samples were taken in the manure circle of the palm (at a distance $1.25 \mathrm{~m}$ from the base at the depth of $0-8 \mathrm{~cm}$ ), at 1 month intervals upto a period of 12 months.

Yield recording: Female flowers, nuts and copra were recorded at bimonthly intervals.

Analytical methods: Total bacterial and fungal counts, ${ }^{7}$ microbial biomass $\mathrm{C},{ }^{8}$ $\mathrm{CO}_{2}$ evolution, ${ }^{9} \mathrm{~N}$ mineralization rate, ${ }^{10}$ nitrification rate, ${ }^{11}$ chemical parameters (total $\mathrm{N}$, available $\mathrm{P}$ and exchangeable $\mathrm{K})^{12}$ and soil moisture ${ }^{13}$ were carried out to assess the soil quality of the control plots and plots treated with various fertilizer combinations mentioned above.

\section{RESULTS}

All fertilizer treatments (organic and inorganic) significantly increased the identified microbiological properties of soil i.e. total bacterial count, total fungal count, microbial biomass $\mathrm{C}, \mathrm{CO}_{2}$ evolution, $\mathrm{N}$ mineralization rate and nitrification rate compared to the control (Fig. 1. to 6). The results showed that addition of organic manure significantly $(p \leq 0.001)$ increased the microbiological parameters in the soil compared with the additions of inorganic fertilizer (Figures 1 to 6). 


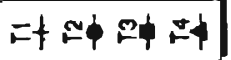
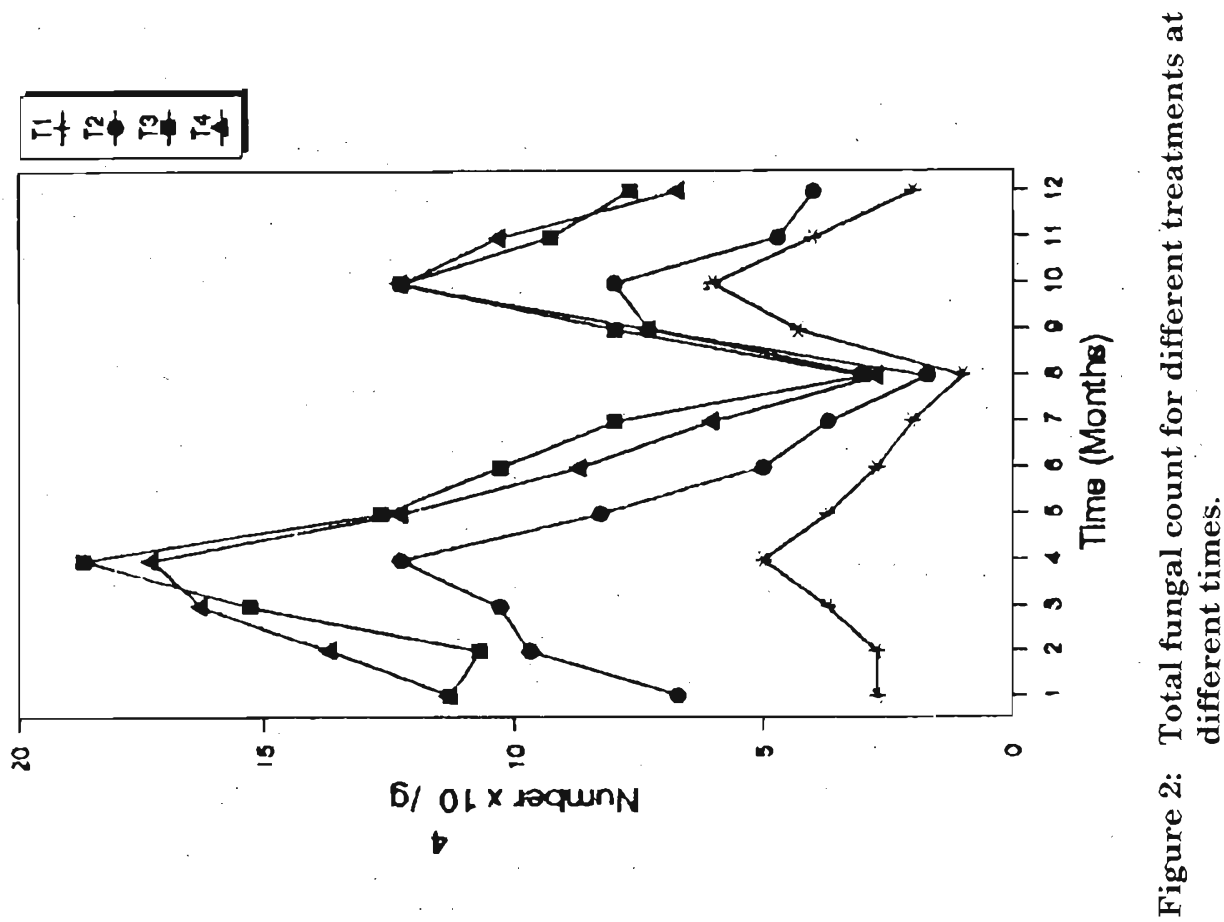

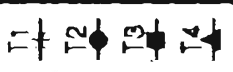

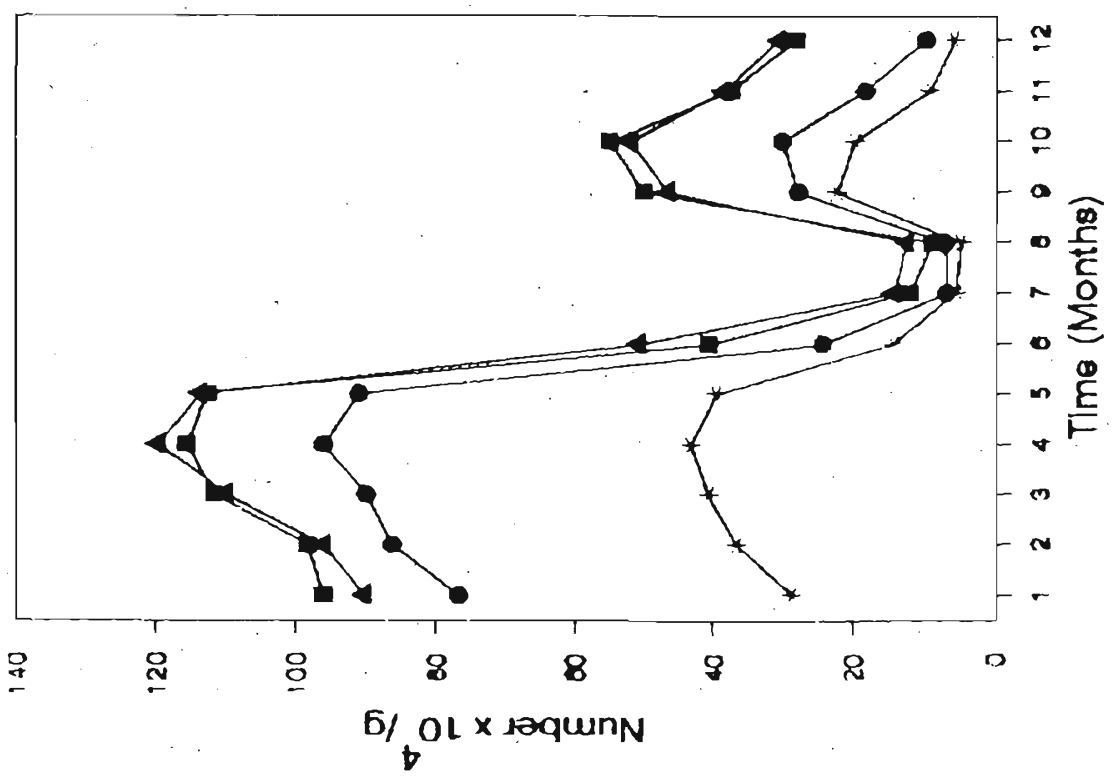



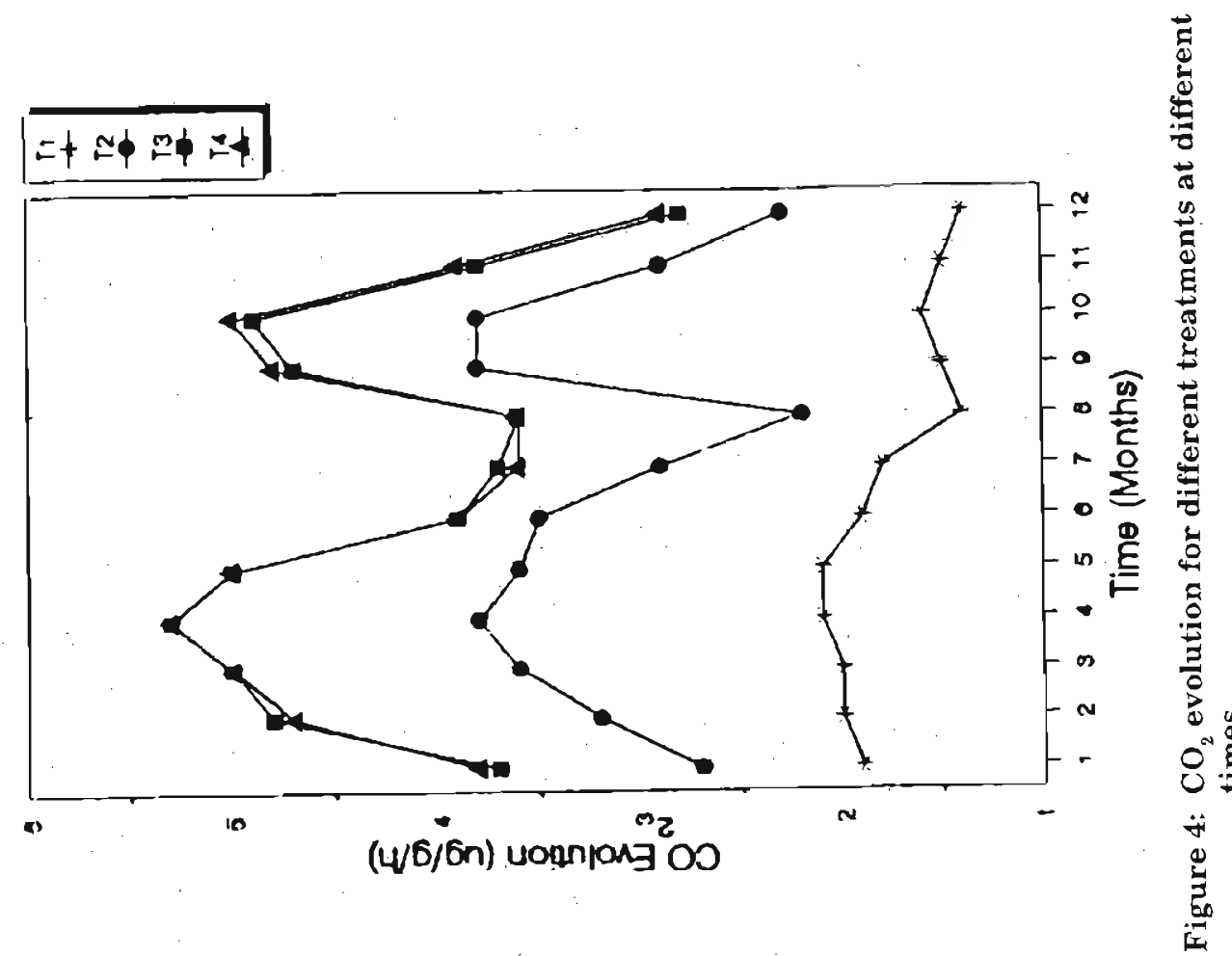

Ft 때 아 하

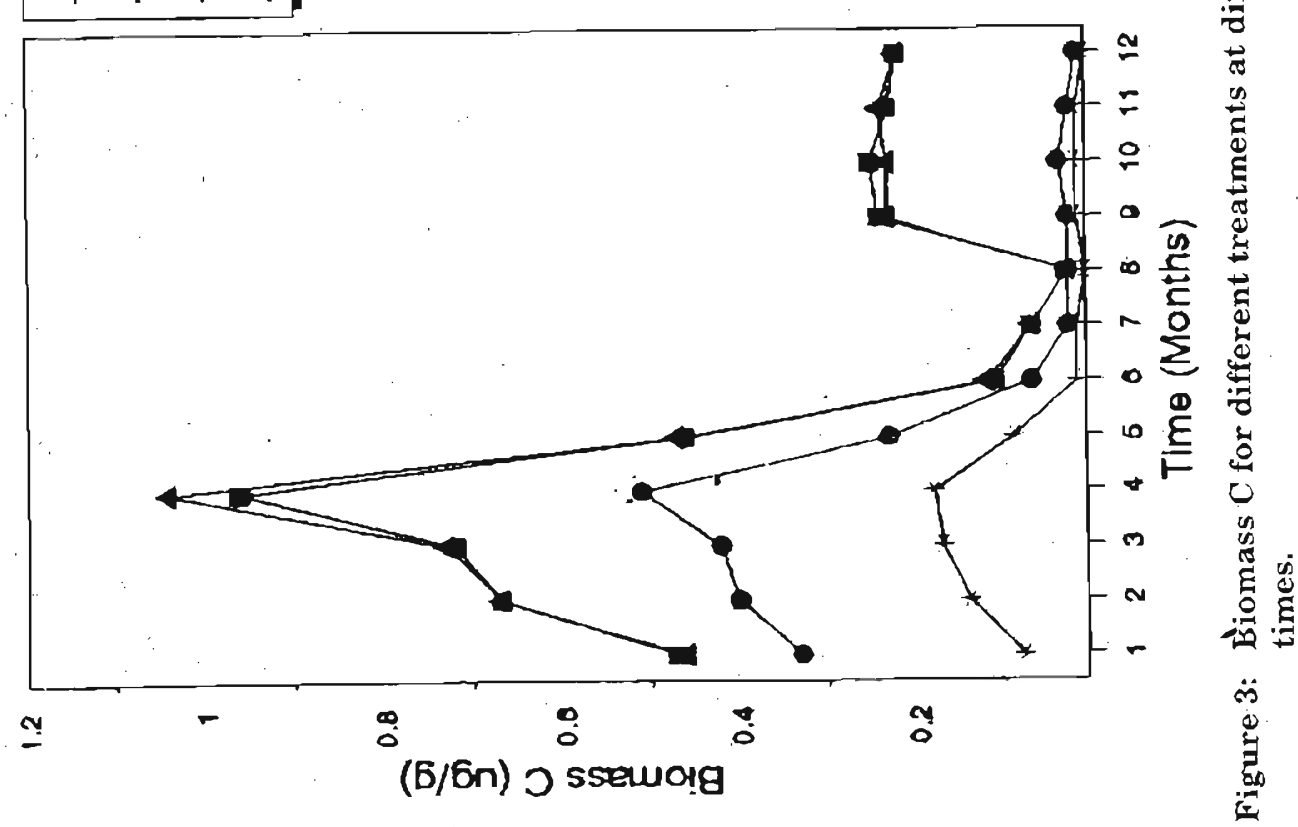




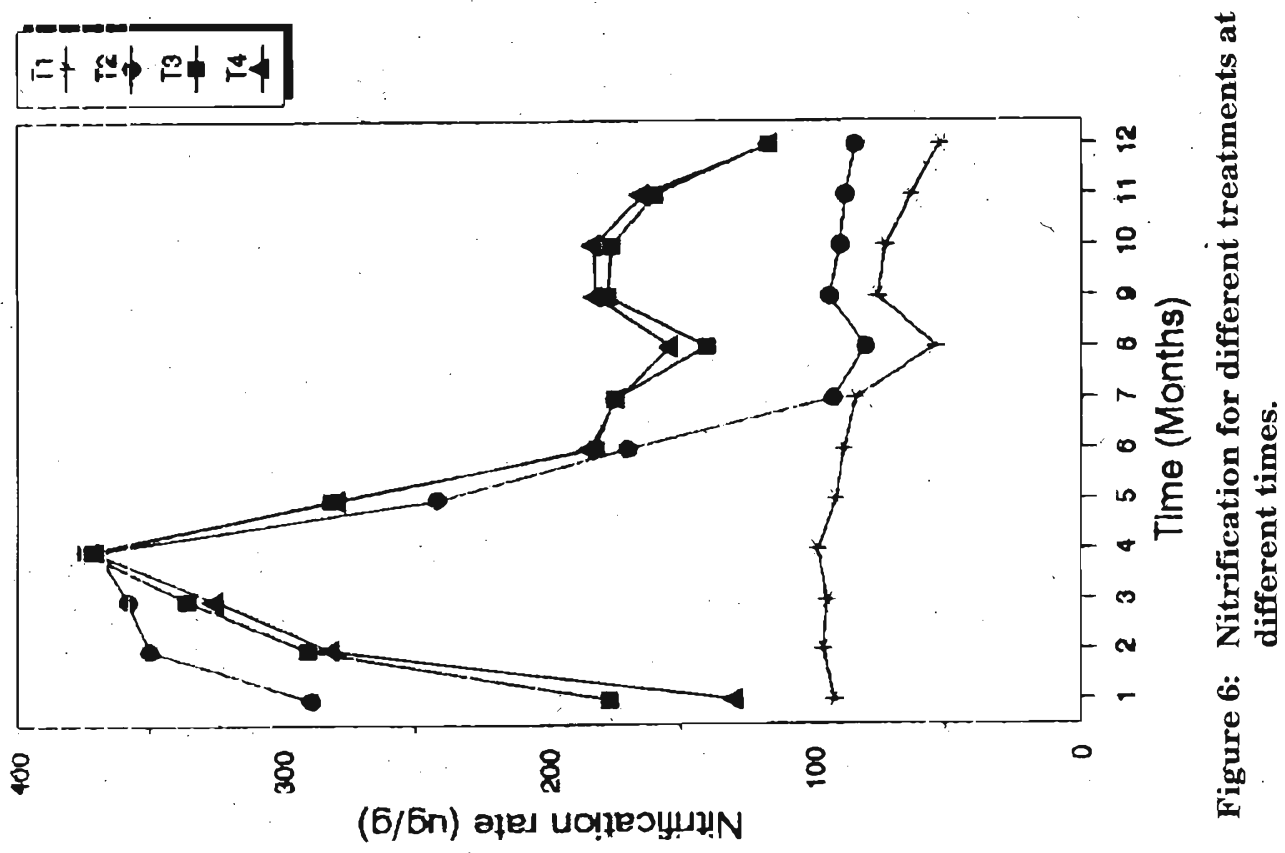

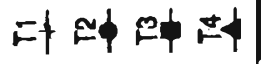

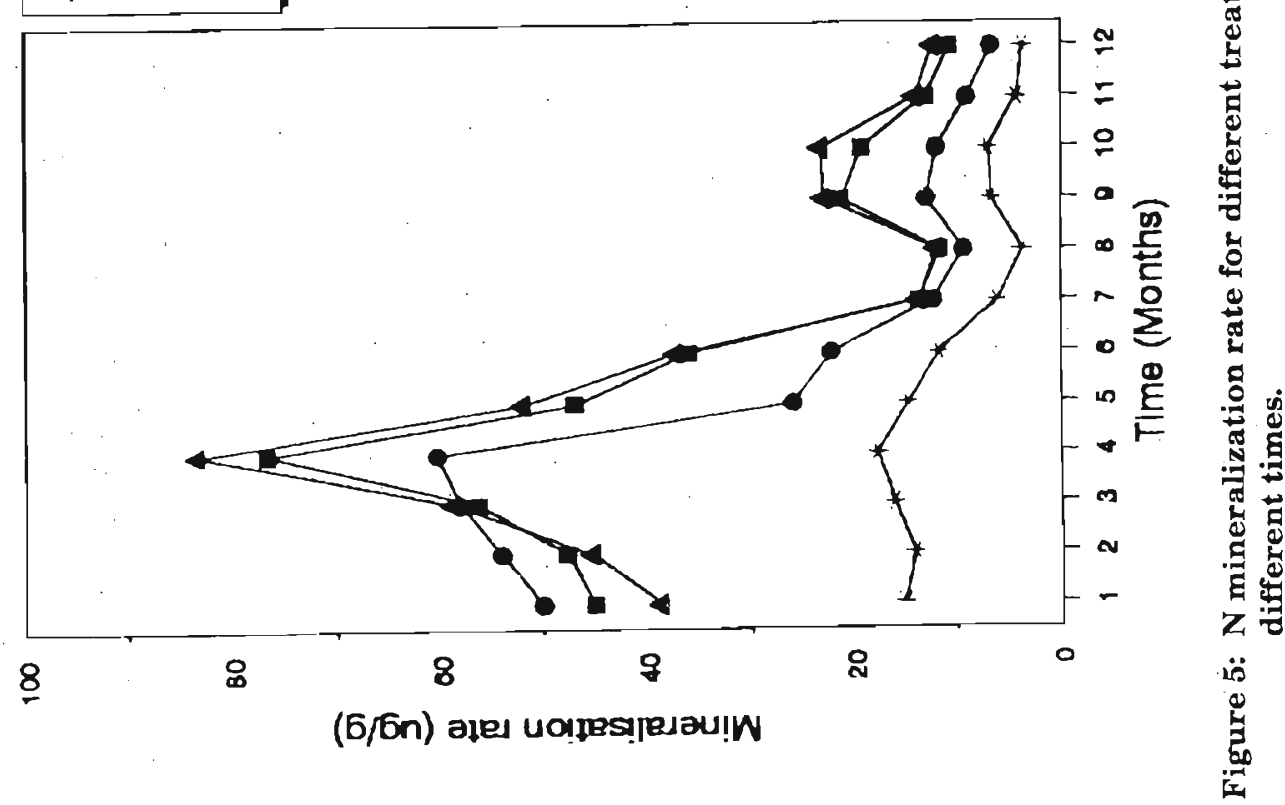


The goat dung treated solid in this study showed an increase in soil moisture $(12-70 \%)$ compared with the control. A significant increase $(p \leq 0.05)$ of soil moisture was also shown compared with inorganic fertilizer (Fig. 7).

The chemical parameters i.e. total $N$, available $P$, and exchangeable $K$, showed significant $(p \leq 0.05)$ increase in the goat dung applied soils than that of the control (Figs. 8 to 10).

The yield parameters of coconut (i.e. female flowers, number of nuts and weight of copra), in the $3 \mathrm{rd}$ year after fertilizer/manure application are given in Table 1. The increase of the yield parameters of coconut in fertilized/manured palms over the control is given in Table 2.

Table 1: Yield parameters of coconut in the 3rd year after fertilizer/manure application.

\begin{tabular}{lccc}
\hline \multicolumn{1}{c}{ Treatment } & $\begin{array}{c}\text { Female } \\
\text { flowers } \\
\text { (no./palm/y) }\end{array}$ & $\begin{array}{c}\text { Number } \\
\text { of nuts } \\
\text { (no./palm/y) }\end{array}$ & $\begin{array}{c}\text { Weight } \\
\text { of copra } \\
(\mathrm{kg} / \mathrm{palm} / \mathrm{y})\end{array}$ \\
\hline $\mathrm{T} 1$ (control) & 88 & 23 & 4.5 \\
$\mathrm{~T} 2$ (inorganic NPK + dolomite) & 119 & 34 & 6.5 \\
$\begin{array}{l}\text { T3 (organic manure + inorganic } \\
\text { NPK + dolomite) }\end{array}$ & 139 & 40 & 7.6 \\
$\begin{array}{l}\text { T4 (organic manure + inorganic } \\
\text { K + dolomite) }\end{array}$ & 136 & 37 & 7.2 \\
\hline
\end{tabular}

Table 2: Yield parameters of coconut (per palm per year) in inorganic fertilizer/ organic manure treated soils over the control, 3 years after fertilizer/ manure application.

\begin{tabular}{lccc}
\hline & Control & $\begin{array}{c}\text { Organic Manure } \\
+ \\
\text { Inorganic fertilizer }\end{array}$ & $\begin{array}{c}\text { Increase } \\
(\%)\end{array}$ \\
\hline Female flowers & 88 & 131 & 49 \\
Number of nuts & 23 & 37 & 61 \\
Weight of copra $(\mathrm{kg})$ & 4.5 & 7.1 & 58 \\
\hline
\end{tabular}




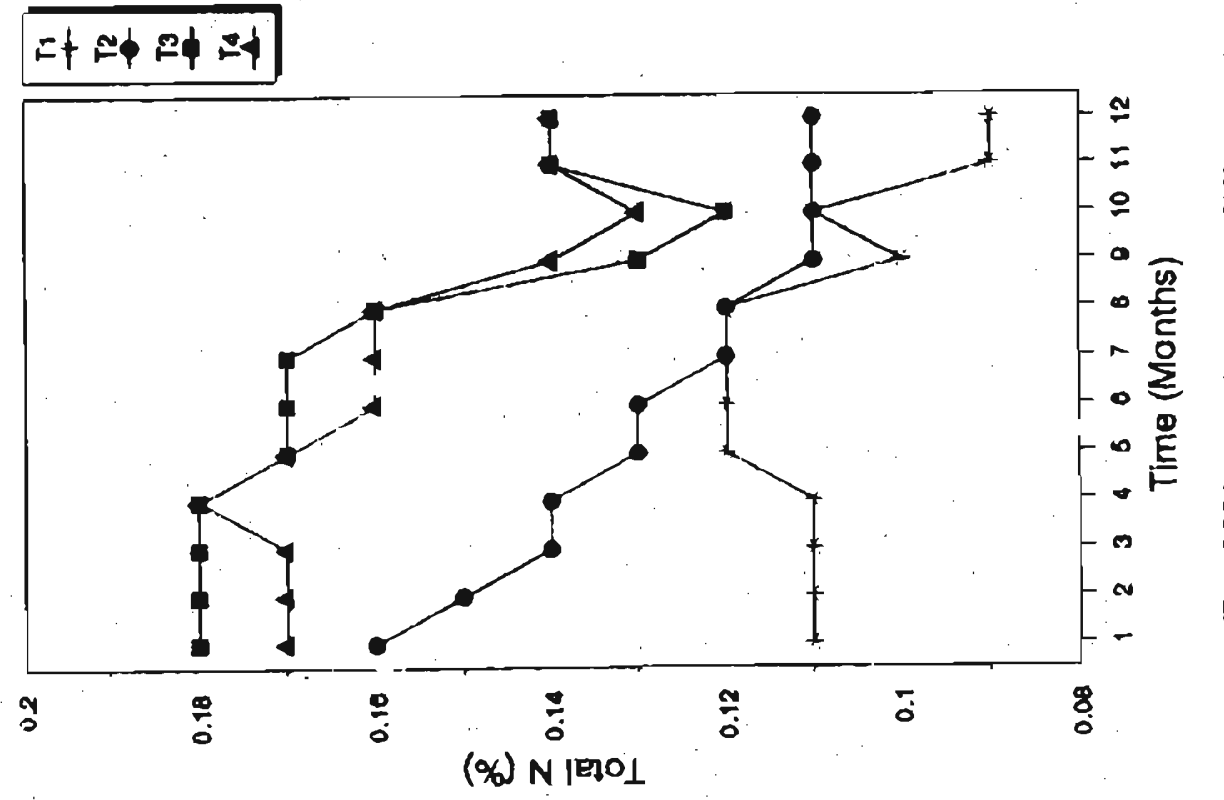

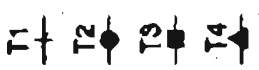

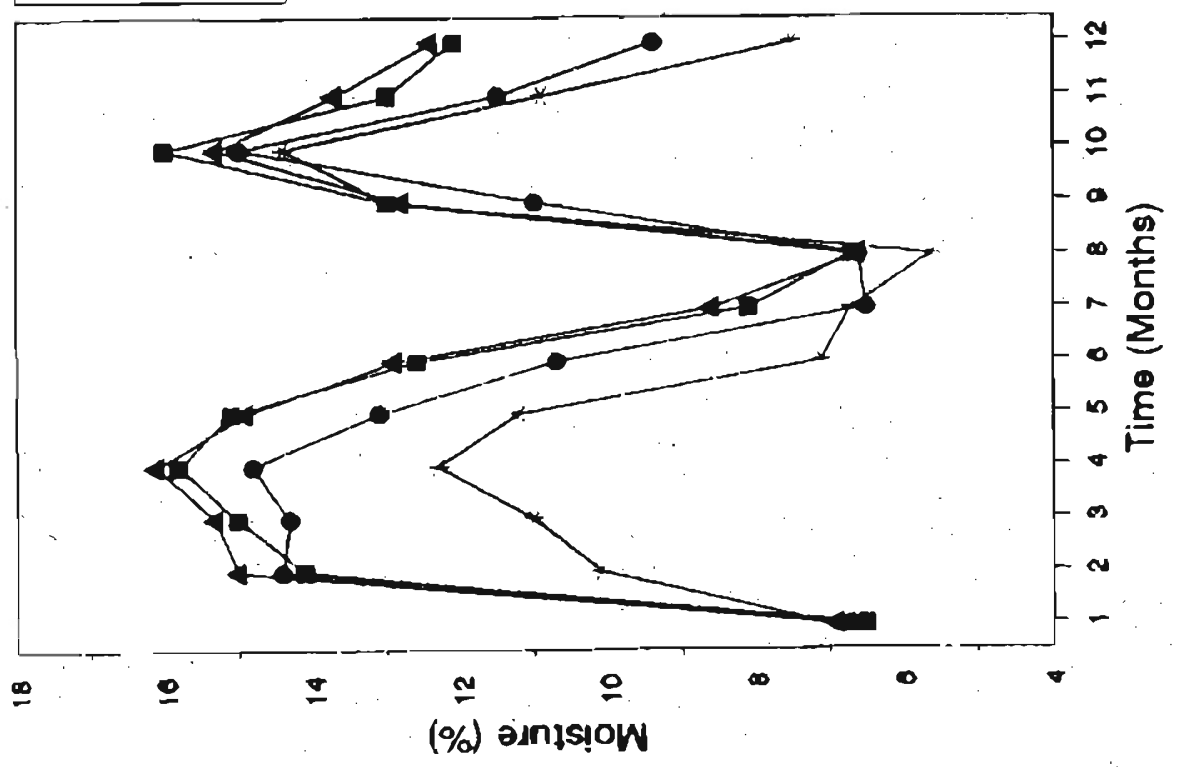




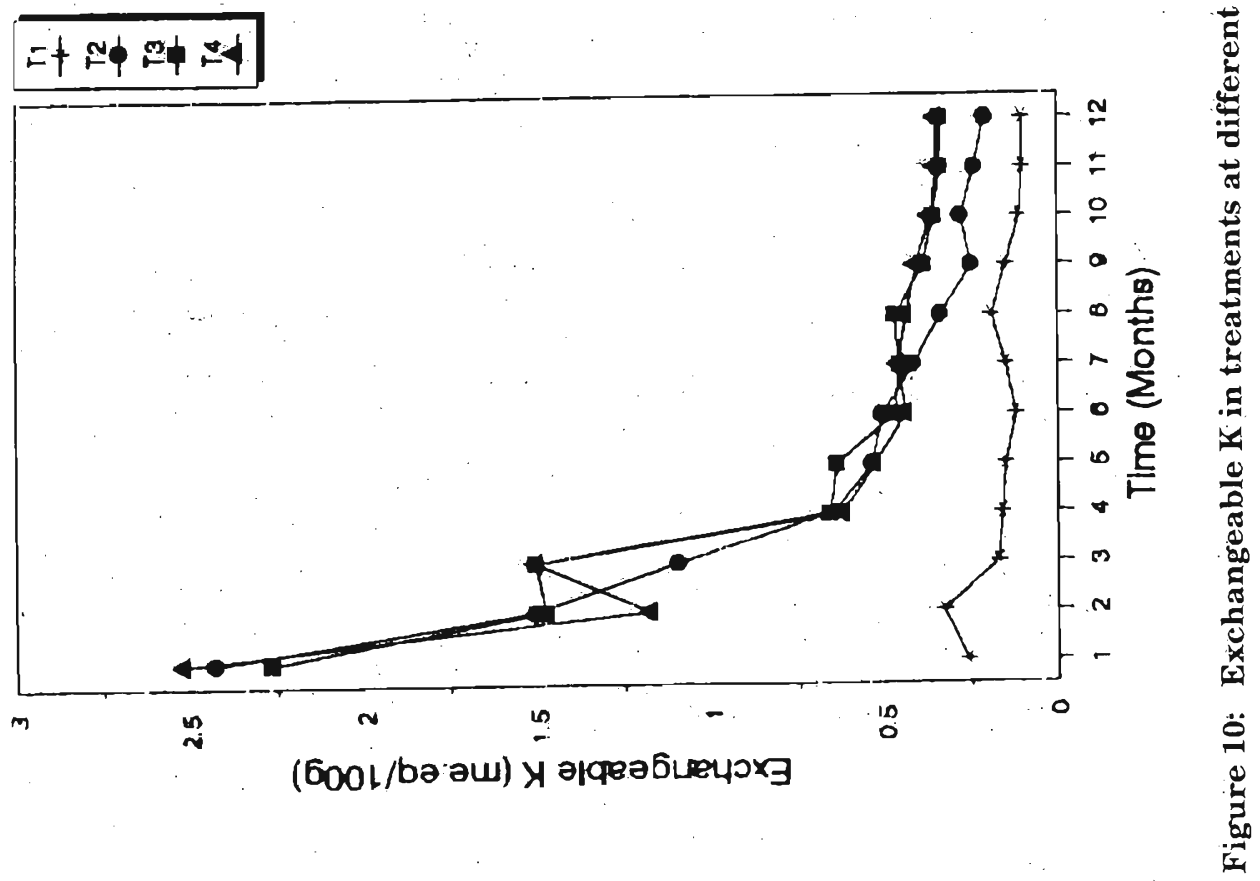

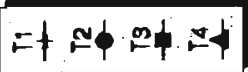

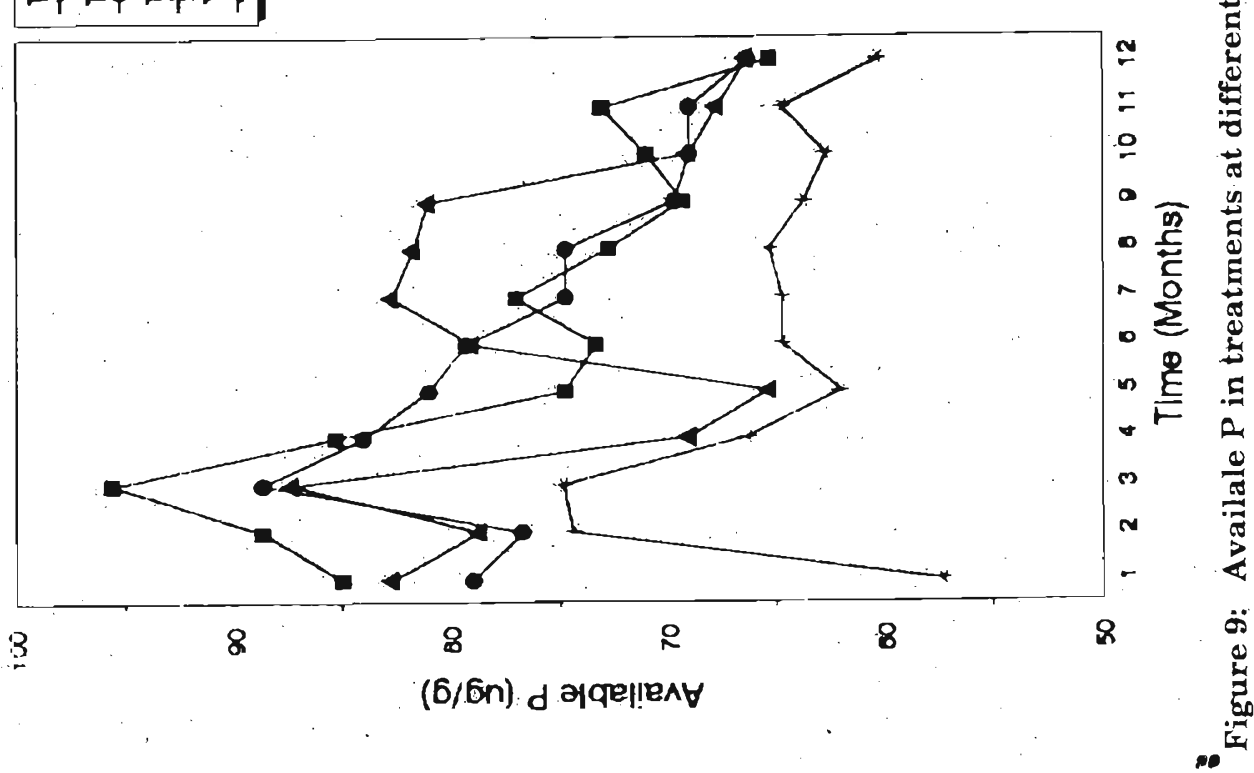




\section{DISCUSSION}

The total bacterial and fungal count of the soil are very important microbiological parameters and indicate the fertility and the activity of the soil. ${ }^{14}$ Increased microbial populations developing in organic manure treated soils contribute to the rapid decomposition and break down of goat dung, releasing nutrients to the palm. Others have reported that the bacterial and fungal populations were also higher in cattle manure treated soils than in soils treated with inorganic fertilizer. ${ }^{15}$ The highest population of bacteria and fungi were also observed in maize straw treated soils compared to inorganic fertilizer treated soils. ${ }^{16}$ Inorganic fertilizer (phosphatic and potassic fertilizers) treated soils showed a highest bacteria and fungi population than control soils. ${ }^{17}$

The bacterial and fungal count showed a significant ( $p \leq 0.001$ ) increase up to about the 4th month and declined thereafter upto the 8th month (Fig. 1 and 2). This is perhaps due to the readily available water soluble constituents of the organic residues enhancing the bacteria and fungal populations. A higher amount of organic $\mathrm{C}$ was also observed in the goat dung treated soils. This has resulted in improving the water holding capacity of the soil. A significant positive correlation was found earlier also between the organic manure content and water holding capacity of the soil. ${ }^{15}$

It is possible that the higher microbial biomass reached in the first 4 months in organic manure treated soils (Fig. 3), is due to the higher organic C content already present in the goat dung. Higher microbial biomass is found in straw supplemented with $\mathrm{N}$ fertilizer treated soil and FYM applied soils than in soils treated with only inorganic $\mathrm{N}$ fertilizer. ${ }^{18}$ Higher microbial biomass is found in only inorganic fertilizer ( $\mathrm{N}$ fertilizer) treated soils than control. ${ }^{18}$ Many workers also showed similar pattern of changes of microbial biomass $\mathrm{C}$ with the applications of organic manure..$^{19,20}$

High $\mathrm{CO}_{2}$ content reflects the microbial activity in the soil. Palms treated with goat dung showed significantly ( $\mathrm{p} \leq 0.001$ ) higher values for $\mathrm{CO}_{2}$ compared with soils treated with only inorganic and no fertilizer treatments (Fig. 4). This may be due to the increase of population of microorganisms after the addition of organic manure.

The mineralization of organic $\mathrm{N}$ is an important determinant of the availability of $\mathrm{N}$ to the palm. The rate of conversion of organic $\mathrm{N}$ to inorganic $\mathrm{N}$ reflects this increase in activity of soil microorganisms. A high rate of $\mathrm{N}$ mineralization in the soils treated with goat dung compared with soils treated with only inorganic and no fertilizer treatments was shown in Figure 5. Similar types of results were obtained when using pig and cattle slurry as the organic sources and $\left(\mathrm{NH}_{4}\right)_{2} \mathrm{SO}_{4}$ as the inorganic fertilizer. ${ }^{21}$ Most of the $\mathrm{N}$ was mineralized in the first 3-4 months, when the biomass was also increasing rapidly. ${ }^{10,20}$ 
Nitrification is influenced mainly by autotrophic bacteria and some of fungi in the agricultural soils. In this study a higher nitrification rate was shown in the goat dung treated soils (Fig. 6) probably as a result of the general increase in the population of microorganisms in these soils which helps in the breakdown of organic materials initially to $\mathrm{NH}_{4}^{+}$and then to $\mathrm{NO}_{2}^{-}$and $\mathrm{NO}_{3}^{-}$. An average increase of $50 \%$ of nitrification rate is shown in goat dung treated soils compared with only inorganic fertilizer treated soils.

The coconut production in Sri Lanka has fluctuated very widely during the last decade, primarily as a result of droughts. In this regard, soil amelioration by the use of organic manure plays an important role.

The increase in nutrient contents $(\mathrm{N}, \mathrm{P}, \mathrm{K})$ shown in the goat dung treated soils during the first 4 month period coincided with increased soil microbiological activities. Hence it could be reasonably assumed that the increased microbiological populations and their activities observed during the first. 4 months after application of goat dung were responsible for its rapid decomposition which released the nutrients to the soil. Many workers reported that the N, P and K increased in the first four months after the addition of different types of organic manures (i.e. cattle manure, compost etc.) to agricuitural soils..$^{22-24}$

As expected the treatments did not show any striking increase of yield parameters over the control during the first two year period. However, in the 3rd year, the treatments showed a significant $(\mathrm{p} \leq 0.05)$ increase in the yield parameters. Initiation of primordium of female flowers normally takes about two years before the inflorescence opens. ${ }^{25}$

Therefore any significant increase evident in the nut production to fertilizer application will be only in two to three years after application of fertilizers. This explains the increase of yield parameters shown only in the 3rd year after the fertilizer application.

\section{References}

1. Smith S.R., Obbard J.P., Kwan K.H.M. \& Jones K.C. (1990). Symbiotic $\mathrm{N}_{2}$ fixation and microbial activity in soils contaminated with heavy metals resulting from long-term sewage sludge application. WRC Research Report FR 0128, WRC, Medmenham, Marlow, U.K.

2. Tomati U., Grappelli A. \& Galli E. (1985). Soil microorganisms and fertility. In: Long-term effect of sewage sludge and farm slurries application (Eds. J.H. Williams, G. Gindi and P.L' Hermite), pp. 14-22. Elsevier Applied Science Publishers, London, U.K.

3. Brady N.C. (1974). The Nature and properties of soils. 8th ed., Macmillan Publishing Co. Inc., New York. 
4. Griffin D.M. (1977). Water potential and wood decay fungi. Annual Review of Phytopathology 15: 319-329.

5. Pidgeon J.D. (1972). The measurement and prediction of available water capacity of ferrallitic soils in Uganda. Journal of Soil Science 23: 431-441.

6. Advisory Leaflets (1984). Coconut Research Institute, Lunuwila, Sri Lanka.

7. Parkinson D., Gray T.R.G. \& Williams S.T. (1971). Methods for studying ecology of soil microorganisms. I.B.P. Hand Book No. 19, International Biological Program, London.

8. Jenkinson D.S. \& Powlson D.S. (1976). The effects of biocidal treatments on metabolism in soil. V A method for measuring soil biomass. Soil Biology and Biochemistry 8: 209-213.

9. Kibble R.A. (1966). Physiological activity in a pinewood soil. Ph.D. Thesis, University of Liverpool, U.K.

10. Smith J.L., Mcneal.B.L., Owens E.J. \& Klock G.O. (1981). Comparison of N mineralization under anaerobic and/or aerobic condition for some agricultural and forest soils of Washington. Communications in Soil Science Plant Analysis 12: 997-1009.

11. Harinton P. (1978). Nitrogen transformation in Arctic soils. M.Sc. Thesis, Calgary University, Canada.

12. Tropical soil and leaf analytical methods (1982). Tropical Soil Analysis Unit, Tropical Soils and Leaf Analytical Centre, U.K.

13. Black C.A. (1965). Methods of soil analysis part 2. Chemical and microbiological properties, American Society of Agronomy Inc., Publisher, Wisconsin, U.S.A.

14. Vigerust $\mathrm{E}$.(1981). Some biological properties in sewage sludge and sewage treated soils. In: The Influence of sewage sludge application on physical and biological properties of soils. (Eds. G. Catroux, P. L' Hermite and E. Suen) pp. 243-349. D. Reidel Publishing Company, U.K.

15. Ramaswami P.R. \& Raj D. (1973), Studies on certain physico-chemical and microbiological properties of the old permanent manurial plot at Coimbatore Madras Agricultural Journal 60: 1001-1005.

16. Shantaram M.V., Balasubramanium A. \& Rangaswami G. (1973). Sequence of soil microflora decomposing maize straw Agricultural Journal 60: 10741079 . 
17. Balasubramaniam A., Shanthanam M.V., Sardeshpande T.S. \& Rangaswamy G. (1972). Studies on certain microbiological properties of the old permanent manurial plots at.Coimbatore. Madras Agricultural Journal 59: 443-448.

18. Schnurer J., Marlanne C. \& Russwall T. (1985). Microbial biomass and activity in an agricultural soil with different organic matter contents. Soil biology and Biochemistry 17: 611-618.

19. Bolton H.J., Ellott L.F. \& Papendicte R.. (1985). Soil microbial biomass and selected soil enzyme activities: effect of fertilization and cropping practices. Soil Biology and Biochemistry 17: 297-300.

20. Smith J.L., Mcneal B.L. \& Cheng H.H. (1985). Estimation of soil microbial biomass. An analysis of the respiratory response of soils. Soil Biology and Biochemistry 17: 11-16.

21. Flowers T.H. \& Arnold P.W. (1983). Immobilization and mineralization of $\mathrm{N}$ in soils incubated with pig slurry or ammonium sulphate. Soil Biology and Biochemistry 15: 329-335.

22. Fellaca D., Ranunne A. \& Scialdone R. (1983). Monthly variations of soluble $P$ in a volcanic ash derived as affected by organic and mineral fertilizers. Plant and Soil 74: 67-74.

23. Gaur A.C. \& Sadasivam KV. (1981). Organic manures in aid of fertilizers. Indian Coconut Journal 10: 31-37.

24. Tiessen H., Karamanos R.E., Stewart J.W.B. \& Sellfs F. (1984). Natural N-15 abundance as an indicator of soil organic matter transformation in native and cultivated soils. Soil Science Society of America Journal 48: 312-315.

25. Abeyewardana V. (1975). Economics of the response of coconut to fertilizer application. Ceylon Coconut Quality 26: 77-85. 